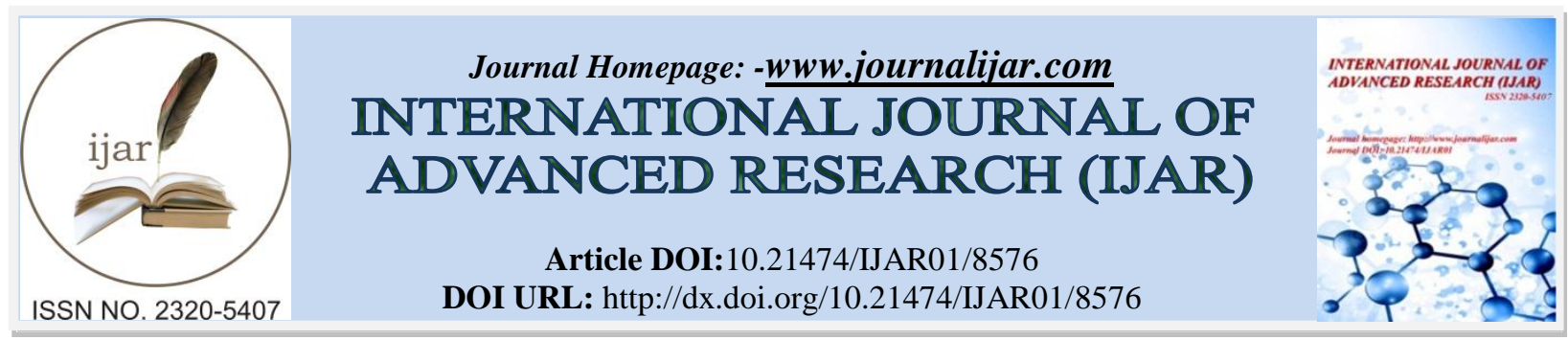

RESEARCH ARTICLE

\title{
THE STRATEGY FOR DEVELOPING MARITIME POTENTIAL AS THE MAIN TASK OF THE NAVY IN SUPPORTING NATIONAL RESILIENCE IN SENDANG BIRU, MALANG(A CASE STUDY).
}

\section{Eko krisdiono $^{1}$, Z. Fanani ${ }^{2}$, moeljadi ${ }^{2}$ and Tjahjanulin ${ }^{2}$.}

1. Postgraduate studentsat brawaijayauniversity .

2. Postgraduate lecturer at brawaijaya university.

\section{Manuscript Info}

Manuscript History

Received: 14 December 2018

Final Accepted: 16 January 2019

Published: February 2019

Key words:-

National Resilience, SWOT Analiysis, Interpretative Structural Modelling,

Balance Scorecard.

\begin{abstract}
Increasing population development, technological developments and the need for food and energy that continues to rise requires a nation to make efforts in its fulfillment, because it can have an impact on the potential threat of national resilience of a nation. The problem examined in this study is a strategy for developing maritime potential in supporting national resilience in the Malang Regency. The purpose of this study is to provide an analysis of the strategy of empowering maritime potential in the SendangBiru area to support national resilience. The method used in this study uses the integration of the SWOT analysis method, Interpretative Structural Modeling (ISM) and Balance Scorecard (BSC). The SWOT analysis is used to identify criteria for national marine security threats, identification of weaknesses and strengths of maritime potential. ISM is used to form a hierarchical relationship between variables in selected strategies while the Balance Scorecard is to create a framework for implementing and evaluating strategies for developing maritime potential in Malang Regency. The results of the study indicate that the chosen and suitable strategy to be implemented is to build maritime domain awareness, meaning knowledge about what is happening at sea in an aquatic area that can have an impact on security and the economy.
\end{abstract}

Copy Right, IJAR, 2019,. All rights reserved.

\section{Introduction:-}

The existence of territory tends to have important values for a country. Geographical value can be seen as a territorial area that describes the sovereignty of the state and even requires a military force to defend it, especially if the region has a wealth of natural resources. Indonesia as an archipelagic country has been recognized internationally through the third United Nations marine law convention, the 1982 United Nations Convention on the Sea of Law (UNCLOS 1982), then ratified by Indonesia under Law No. 17 of 1985 (Putri, 2017). According to UNCLOS 1982, the total area of Indonesia's sea is 5.9 million km2, consisting of 3.2 million km2 of territorial waters and $2.7 \mathrm{~km} 2$ of waters in the Exclusive Economic Zone, this watershed does not include continental shelf.

In the current era of globalization, Indonesia as an archipelagic country has potential problems that pose a threat to an island nation. The threat is in the form of violations of law which include piracy, people smuggling, smuggling of goods, illegal fishing, sea pollution, illegal exploration and exploitation of natural resources, and other violations in

Corresponding Author:-Eko krisdiono.

Address:-Postgraduate studentsat brawaijaya university. 
the sea area. An overview of global trends in the fields of population, food supply, non-renewable and renewable resources, and environmental impacts including global climate change shows that the situation has changed significantly during the first decade of the twenty-first century.

Increasing population and increasing middle class groups will affect the increase in purchasing power and encourage increased food consumption. When food productivity decreases, it certainly impacts on social, economic, and political issues that develop in society. This then will slowly give birth to a threat to global security.The dynamics of the global environment will always have an influence on national development, both positive and negative influences. Positive influence will benefit the government in supporting national policy lines, while negative influences will pose a potential threat to national stability.

The dynamics of the global environment will always have an influence on national development, both positive and negative influences. Positive influence will benefit the government in supporting national policy lines, while negative influences will pose a potential threat to national stability.The method used is an integration in answering problems that exist in Indonesia, especially in Malang Regency. the integration method of SWOT analysis is very effective for determining the influence of internal and external factors, after the strategy is identified from the SWOT analysis the Interpretative Structural Modeling (ISM) method is very appropriate to determine the relationship between the components contained in the selected sub strategy while the Balance Scorecard (BCS) is very effective and it is appropriate to make a strategic goal and evaluation plan in developing maritime potential in Malang Regency.

This study also refers to previous studies such as research with titles Empirical Study of Fitness Industry CasesBased on SWOT (Chang \& Yang, 2013), Coping with Imprecision in Strategic Planning: A Case Study Using Fuzzy SWOT Analysis (Hosseini-Nasab, Hosseini-Nasab, \& Milani, 2011), SWOT Analysis of Central Economical Zone Developing E-Commerce-Take Henan for Example (Ge, 2016), A SWOT Analysis of Maritime Transportation and Security in the Gulf of Guinea (Ofosu-Boateng, 2017), Modelling and analysis of FMS productivity variables by ISM, SEM and GTMA approach (Jain \& Raj, 2014), ISM for analysing the safety of SRRMs (George \& Pramod, 2013), ISM analysis of CPFR implementation barriers (Panahifar, Byrne, \& Heavey, 2014), Performance Measurement Analysis of Palm Cooperative Cooperation with Using Balanced Scorecard (Muda, et al., 2017), Analyzing key performance indicators of e-commerce using balanced scorecard (Chaharsooghi, Beigzadeh, \& Sajedinejad, 2016) and Performance Measurement Using Balanced Scorecard Concept On Co-Operatives: Implication In Indonesia (Ernita \& Firmansyah, 2015).

\section{Research purposes:-}

The purpose of this study is to provide an analysis of the strategy of empowering maritime potential in the SendangBiru area to support national resilience.

\section{Research Methods:-}

To solve problems in the observed research, steps are needed and determined to describe the approach and model of the problem. The steps taken are:

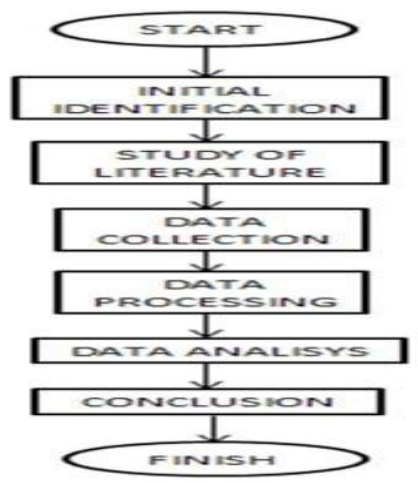


Figure 1:-Research Methodology Flowchart.

The concept of Strength, Weakness, Opportunity, Threat (SWOT) Analysis:-

SWOT analysis is one of several strategic planning tools used in businesses and organizations to ensure that there are clear objectives for the project or business (Osita, R., \& Justina, 2014). Analysis using SWOT has a tendency to superficial theoretical roots (Valentin, 2005). SWOT analysis is the most common technique that can be used to analyze strategic cases. we can see that the definition of analysis using SWOT is related tocareful consideration (Abubakar \& Garba Bala Bello, 2013). SWOT is a tool that is often used to analyze internal and external environments to achieve systematic approaches and support for decision situations. SWOT is an acronym of strength $(\mathrm{S})$, weakness $(\mathrm{W})$, opportunity $(\mathrm{O})$ and threat $(\mathrm{T})$. The first two factors (strengths and weaknesses) are related to internal organizational factors, while opportunities and threats cover the broader context or environment in which the entity operates.

Internal and external factors are referred to as strategic factors, and are summarized in the SWOT analysis. Strengths and weaknesses are factors in the system that allow and prevent the organization from achieving its objectives. Opportunities and threats are considered as external factors that facilitate and limit the organization in achieving its own goals. SWOT analysis shows the right strategies in four categories SO, ST, WO and WT. The strategy identified as SO, involves taking advantage of opportunities using existing strengths. ST is a strategy related to the use of force to eliminate or reduce the effects of threats. Likewise, the WO strategy seeks to benefit from the opportunities presented by external environmental factors by paying attention to its weaknesses. The fourth and final is WT, where the organization tries to reduce the impact of its threat by considering its weaknesses. SWOT analysis can be used to summarize the main issues of the business environment and strategic capabilities of an organization that are most likely to have an impact on the development of the strategy (Khan, Alam, \& Alam, 2015).

Table 1:-Matrix SWOT Analysis

\begin{tabular}{|c|c|c|}
\hline $\begin{array}{c}\text { INTERNAL/EXTERNAL } \\
\text { FAKTOR }\end{array}$ & $\begin{array}{c}\text { STRENGTH(S) } \\
\text { (Maximal) }\end{array}$ & $\begin{array}{c}\text { WEAKNESS(W) } \\
\text { (Minimal) }\end{array}$ \\
\hline $\begin{array}{c}\text { OPPORTUNIT|IS(O) } \\
\text { (maximal) }\end{array}$ & $\begin{array}{c}\text { S-OStrategy } \\
\text { (Maximal-Maximal) }\end{array}$ & $\begin{array}{c}\text { W-TStrategy } \\
\text { (Minimal-Minimal) }\end{array}$ \\
\hline $\begin{array}{c}\text { THREATS(T) } \\
\text { (Minimal) }\end{array}$ & $\begin{array}{c}\text { S-TStrategy } \\
\text { (Maximal-Minimal) }\end{array}$ & $\begin{array}{c}\text { W-OStrategy } \\
\text { (Minimal-Maximal) }\end{array}$ \\
\hline
\end{tabular}

The Concept of Interpretative Structural Modeling (ISM):-

Interpretive structural modeling (ISM) is used for ideal planning, is an effective method because all elements can be processed in a simple matrix. ISM was first proposed by Warfield in 1973. Analysis using ISM begins with identification of variables, which are relevant to the problem being discussed and then the solution technique is determined (Attri, Dev, \& Sharma, 2013). Interpretive structural modeling is a methodology that aims to identify the relationship between certain items, which defines a problem or related issue and a suitable modeling technique to analyze the influence of one variable on another variable (Aalam, Arshad, \& Khan, 2017).

ISM has been well proven to identify structural relationships between system-specific variables. The basic idea is to use practical experience and expert knowledge to break down complex systems into sub-systems and build multilevel structural models. ISM is a learning process that allows individuals or groups to develop maps of complex relationships between many elements involved in complex situations. The ISM-based approach is one of the most versatile and powerful techniques that has been used to solve complex multi-factor problems. The ISM is interpretative, because the assessment of the group chosen for the study determines whether and how the variables are related. 
This ISM method can find the main subfactor and is able to provide a real picture of the hierarchical structure of the subfactor as a knowledge base that can be applied (Approach Using Interpretive Structural Model (ISM) to Determine Key Sub-Factors at Factors: Benefits, Risk Reductions, Opportunities and Obstacles in Awareness it Governance , 2018).ISM is often used to provide a basic understanding of complex situations, and to develop a series of actions to solve a problem. The ISM starts with identifying elements that are relevant to the problem or problem and extends to group problem solving techniques. A structural self interaction matrix (SSIM) is developed based on a comparison of pairs of elements.

For developing SSIM, the following four symbols have been used to denote the direction of relationship between KSBs ( $\mathrm{i}$ and $\mathrm{j}$ ): $\bullet \mathrm{V}$ is used for the relation from KSB $\mathrm{i}$ to KSB $\mathrm{j}$ (i.e. if KSB i influences or reaches to KSB $\mathrm{j}$ ).

1. A is used for the relation from KSB $\mathrm{j}$ to $\mathrm{KSB} i$ (i.e. if $\mathrm{KSB} \mathrm{j}$ reaches to KSB $\mathrm{i}$ ).

2. $\mathrm{X}$ is used for both direction relations (i.e. if KSB $\mathrm{i}$ and $\mathrm{j}$ reach to each other).

3. $\mathrm{O}$ is used for no relation between two KSB (i.e. if KSB $\mathrm{i}$ and $\mathrm{j}$ are unrelated).

Table 2:-Structural Self-Interaction Matrix (SSIM):

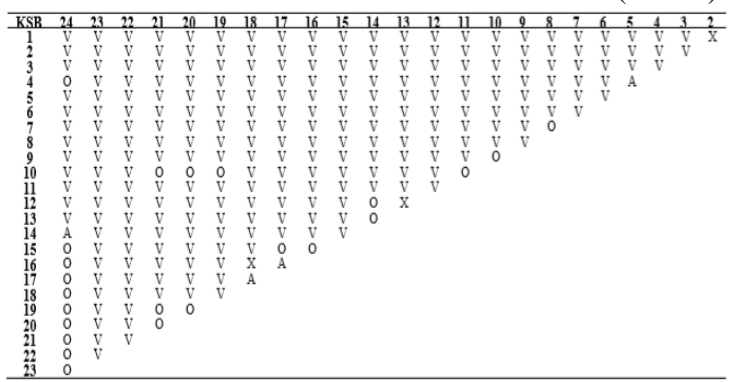

Sub-elements are classified into 4 quadrants, namely :

1. AUTONOMOUS (weak driver-weak dependent variables), that is sub element with DP value $<0.5 \mathrm{X}$ and $\mathrm{D}$ value $<0.5 \mathrm{X}$ where $\mathrm{X}$ is the number of subelements. Generally, sub-elements in this sector are not associated with the system, and may have low relationship even though the relationship can be strong.

2. DEPENDENT (weak driver-strongly dependent variables) that is sub element with DP value $<0.5 \mathrm{X}$ and $\mathrm{D}$ value $>0.5 \mathrm{X}$. Sub-elements in this sector is dependent.

3. LINKAGE (strong driver-strongly dependent variables) that is sub element with DP value $>0.5 \mathrm{X}$ and $\mathrm{D}$ value $>0.5 \mathrm{X}$. Sub-elements in this sector should be studied carefully because relationship among sub-elements is unstable. Every action on the sub elements will have impact on other sub-elements and the feedback effects can magnify the impact.

4. INDEPENDENT (strong driver-weak dependent variables) that is sub element with DP value $>0.5 \mathrm{X}$ and $\mathrm{D}$ value $<0.5 \mathrm{X}$. Sub-elements in this sector are the rest of system and are called as independent variables.

\section{The Concept of Balance Scorecard (BSC):-}

The Balanced Scorecard is a strategic planning model that can be used by any organization for achieve good breakthrough results (Ronchetti, 2006).This method of measuring performance with the Balanced Scorecard was first introduced by Kaplan and Norton. The Balanced Scorecard method is one method of measuring strategic and systematic performance, which tries to involve the overall perspective involved in the company simultaneously, namely: financial (financial) perspective; Learning and growth perspective (learning and growth), internal business process perspective (company internal processes), and customer (customer) perspective.

The Balanced Scorecard emphasizes that financial and nonfinancial measures must be part of the information system for all employees in the company, both subordinate employees, leaders, top managers of the company (Alrafadi \& Md-Yusuf, 2011). In line with this, the tools to meet the steps that are better than the ability of a company that will be able to create long-term value by identifying the key relevant drivers (Alao \& Esther, 2013). The goals of the measurements in the Balanced Scorecard are not a collection of performance measures, but rather are derived from the company's vision, mission and strategy in tangiable goals and sizes.

After recording the success of applying the Balanced Scorecard as an expansion of executive performance, the Balanced Scorecard is then applied to a more strategic management stage before performance appraisal. In planning 
systems, performance measurement occurs at the implementation stage of the plan. Personnel cannot be held accountable for their performance if at the planning stage, these personnel do not plan performance that will be realized in the future. Therefore, following the successful implementation of the Balanced Scorecard in 1992, the Balanced Scorecard approach was then applied in the planning process.

Starting in 1993, Renaissance Solution, Inc. (RSI) a consulting company led by David P. Norton implemented the Balanced Scorecard as an approach to translating and implementing strategies in various client companies. From then on, the Balanced Scorecard no longer only functions as a performance measurement tool, but develops into the core of the strategy management system. In the beginning of 2000, the Balanced Scorecard has become the core of the strategy management system, not only for executives, but for all company personnel, especially in companies that have used information technology intensively in their business operations. The Balanced Scorecard provides a clear and reasonable framework for all personnel to produce financial performance through the realization of various non-financial performance.

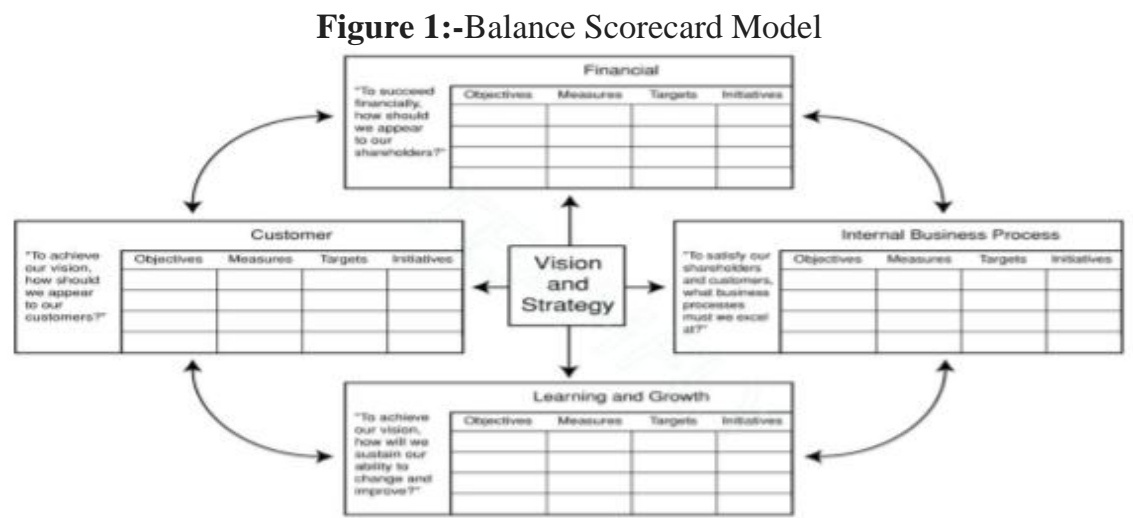

The summary of the four perspectives, namely:

1. Financial perspective, providing financial goals that need to be achieved by the organization in realizing its vision.

2. Customer perspective, provides an overview of the targeted market segments and customers along with the demands of the needs served by the organization in an effort to achieve certain financial goals.

3. Internal and process business perspective, provides an overview of the processes that must be built to serve customers and to achieve certain financial goals.

4. Learning and growth perspective, is a driver for building personnel competencies, information system infrastructure and the atmosphere of the work environment needed to realize financial goals, customers and internal business processes.

\section{Strategy Management:-}

Management strategies can be defined as art and science in formulating, implementing, and evaluating crossfunctional decisions that enable organizations to achieve their goals. This definition implies that strategic management focuses on integrating management, marketing, finance / accounting, production / operations, research and development, and information systems to achieve organizational success. The term strategic management in this text is used synonymously with the term strategic planning. The latter term is more often used in the business world, while the first is often used in the academic world.

The aim of management strategy is to utilize and create new and different opportunities for tomorrow; Long-term planning, on the contrary, tries to optimize for tomorrow's trends today. The results of strategic plans from managerial choices are difficult among many good alternatives, and that signifies commitment to certain markets, policies, procedures, and operations in lieu of other action programs.

Strategic management has now evolved to the point where its core value is in helping organizations operate successfully in a dynamic and complex environment. To be competitive in a dynamic environment, companies become less bureaucratic and more flexible. In a stable environment like in the past, competitive strategies only involve defining competitive positions and then maintaining them.

Strategic environment as a macro category environment can be analyzed using PESTEL devices (Politics, Economy, Social-Culture, Technology, Environmental, Legal). The analysis only measures the relevant elements that affect the 
life or course of an organization or a particular entity in the specified period. Then an assessment of the level of influence of these elements will be carried out relative to that particular organization or entity. Through analysis of PESTEL devices, it can be described the level of threats and opportunities for certain organizations.

Thus the strategic environment surrounding maritime security will be assessed through political, economic, sociocultural, technological, environmental and legal factors if each of these factors has a strong relevance to maritime security. In each of these factors a number of phenomena variables will be selected which will be the basis for assessing the level of influence of each of these factors on maritime security.

The role and duties of the navy:-

In the strategy of developing the Maritime Potential, it cannot be separated from the role and duties of the Navy. The task and role of the Navy in the future due to the dynamic development of the global, regional and national strategic environment will be increasingly complex.

In accordance with Article 9 of Law Number 34 of 2004 concerning the Indonesian National Army, the duties of the Navy are as follows: 1) Carry out the duties of the Indonesian National Army in the defense sector, 2) Uphold the law and maintain security in the sea area of national jurisdiction in accordance with the provisions of national law, ratified international law, 3) Carry out the duties of Navy diplomacy in order to support foreign policy set by the government, 4) Carry out the duties of the Indonesian National Army in the development and development of the power of the sea, 5) Carry out empowerment of sea defense areas.

\section{Research Time and Location:-}

This research was conducted in Sendang Biru, Malang Regency.While the time of research starts on October 2018 until Desember 2018..

\section{Result And Analysis:- SWOT Analysis:-}

The SWOT analysis data was obtained through observations on the object of research on the basis of the existing theory and then proceeded with interviews on the object of the assessment after quisioning was carried out on stakeholders in the SendangBiru area of Malang district. In analyzing with the SWOT method approach, stages of identification of aspects and criteria are carried out which are the variables in the study. The research aspects and criteria identified were influential variables and interacted with the SendangBiru area development strategy.

Variable Identification Stages carried out by conducting literature studies and conducting interviews with Expert. From the process of understanding the study of literature and conducting interviews with the Expert, there are influential variables. The following is the identification of the variables shown in table 3 .

Table 3:-strategy approach matrix

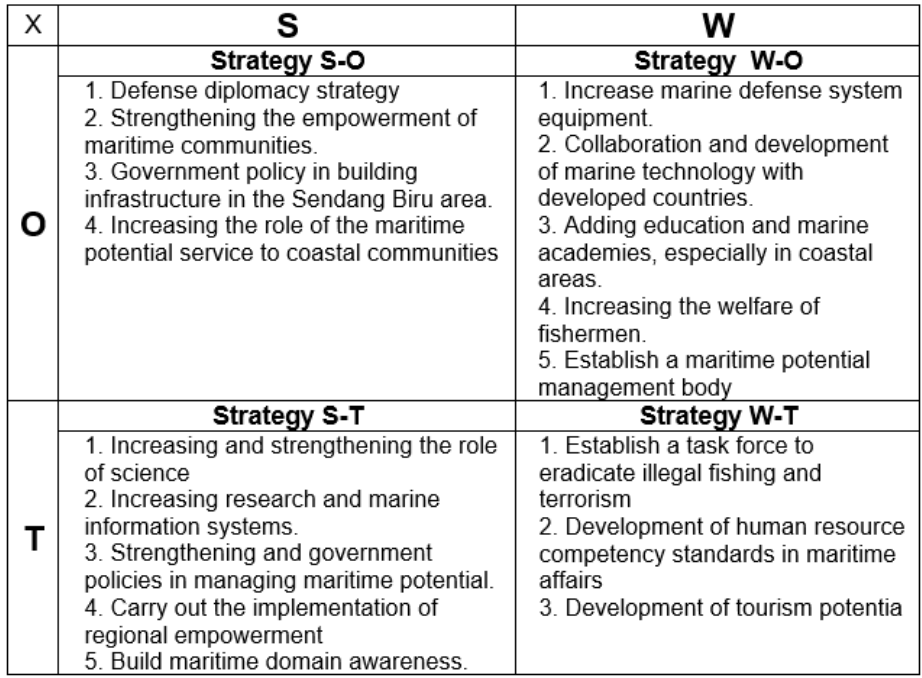


Based on data on the strengths, weaknesses, opportunities and threats that have been obtained and then developing a strategic approach Strenght - Opportunities use existing forces to create opportunities, Strength - Threats uses existing forces to avoid and eliminate the threats that exist, Weakness - Opportunities eliminate weaknesses that exist to create opportunities, Weakness - Threat eliminates weaknesses to avoid threats.

Table 4:-Symbol and strategy in SWOT

\begin{tabular}{|c|c|c|}
\hline No & Strategy & Symbol \\
\hline 1 & Defense diplomacy strategy & $(\mathrm{SO}) 1$ \\
\hline 2 & Strengthening the empowerment of maritime communities. & $(\mathrm{SO}) 2$ \\
\hline 3 & $\begin{array}{l}\text { Government policy in building infrastructure in the Sendang Biru } \\
\text { area. }\end{array}$ & $(\mathrm{SO}) 3$ \\
\hline 4 & $\begin{array}{l}\text { Increasing the role of the maritime potential service to coastal } \\
\text { communities }\end{array}$ & $(\mathrm{SO}) 4$ \\
\hline 5 & Increase marine defense system equipment. & $(\mathrm{WO}) 1$ \\
\hline 6 & $\begin{array}{l}\text { Collaboration and development of marine technology with } \\
\text { developed countries. }\end{array}$ & (WO)2 \\
\hline 7 & $\begin{array}{l}\text { Adding education and marine academies, especially in coastal } \\
\text { areas. }\end{array}$ & $(\mathrm{WO}) 3$ \\
\hline 8 & Increasing the welfare of fishermen. & $(\mathrm{WO}) 4$ \\
\hline 9 & Establish a maritime potential management body & $(\mathrm{WO}) 5$ \\
\hline 10 & Increasing and strengthening the role of science & (ST) 1 \\
\hline 11 & Increasing research and marine information systems. & (ST)2 \\
\hline 12 & $\begin{array}{l}\text { Strengthening and government policies in managing maritime } \\
\text { potential. }\end{array}$ & (ST)3 \\
\hline 13 & Carry out the implementation of regional empowerment & (ST)4 \\
\hline 14 & Build maritime domain awareness & (ST)5 \\
\hline 15 & Establish a task force to eradicate illegal fishing and terrorism & (WT)1 \\
\hline 16 & $\begin{array}{l}\text { Development of human resource competency standards in } \\
\text { maritime affairs }\end{array}$ & (WT)2 \\
\hline 17 & Development of tourism potentia & (WT)3 \\
\hline
\end{tabular}

Based on the SWOT analysis, the total strategy that has been formulated is seventeen sub-strategies that determine the strategy for developing maritime potential to support the task of the Navy to support national resilience. The next stage of the strategy will be modeled in the ISM method.

\section{ISM Analysis:-}

The first step in processing ISM is to create a Structural Self Interaction Matrix (SSIM), where contextual relationships are made by variables $i$ and variables $j$. Modeling engineering is done by incorporating the results of the evaluation of the strategic environment into input model elements. In this study strategic environmental evaluation uses SWOT which is a framework of factors Strengths, Weaknesses, Opportunities and Threats. Strategy formulation which is the interaction between internal and external factors SWOT is SO strategy (interaction of strengths and opportunities), WO strategy (interaction of weaknesses and opportunities), ST strategy (interaction of strengths and threats) and WT strategies (interaction of weaknesses and threats).

Table 5:-Matrix SSIM-VAXO

\begin{tabular}{|c|c|c|c|c|c|c|c|c|c|c|c|c|c|c|c|c|c|c|c|c|}
\hline \\
\hline No & Strategy & $x$ & 1 & 2 & 3 & 4 & 5 & 6 & 7 & 8 & 9 & 10 & 11 & 12 & 13 & 14 & 15 & 16 & 17 & $\mathrm{DP}$ \\
\hline 1 & Defense diplomacy strategy & 1 & 1 & 0 & 0 & 0 & 1 & 1 & 1 & 0 & 1 & 0 & 1 & 1 & 1 & 1 & 1 & 1 & 1 & 12 \\
\hline 2 & Strengthening the empowerment of maritime communities. & 2 & 0 & 1 & 1 & 1 & 0 & 1 & 1 & 1 & 1 & 1 & 0 & 1 & 1 & 1 & 1 & 1 & 1 & 14 \\
\hline 3 & Government policy in building infrastructure in the Sendang & 3 & 0 & 0 & 1 & 1 & 1 & 1 & 1 & 1 & 1 & 1 & 1 & 1 & 1 & 1 & 1 & 0 & 1 & 14 \\
\hline 4 & Increasing the role of the maritime potential service to coss & 4 & 0 & 1 & 1 & 1 & 0 & 1 & 0 & 1 & 0 & 1 & 1 & 1 & 1 & 1 & 1 & 1 & 1 & 13 \\
\hline 5 & Increase marine defense system equipment. & 5 & 1 & 0 & 1 & 0 & 1 & 0 & 1 & 0 & 0 & 1 & 1 & 1 & 1 & 1 & 1 & 0 & 0 & 10 \\
\hline 6 & Collaboration and development of marine technology with & 6 & 1 & 0 & 1 & 1 & 0 & 1 & 1 & 1 & 0 & 0 & 1 & 1 & 1 & 1 & 0 & 1 & 1 & 12 \\
\hline 7 & Adding education and marine academies, especially in $\infty 8$ & 7 & 0 & 1 & 1 & 0 & 0 & 0 & 1 & 1 & 0 & 1 & 1 & 1 & 1 & 1 & 1 & 1 & 0 & 11 \\
\hline 8 & Increasing the welfare of fishermen. & 8 & 0 & 1 & 1 & 1 & 0 & 0 & 0 & 1 & 1 & 1 & 1 & 1 & 1 & 1 & 1 & 1 & 0 & 12 \\
\hline 9 & Establish a maritime potential management body & 9 & 1 & 1 & 1 & 0 & 0 & 0 & 0 & 0 & 1 & 1 & 1 & 1 & 1 & 1 & 1 & 1 & 1 & 12 \\
\hline 10 & Increasing and strengthening the role of science & 10 & 0 & 1 & 0 & 0 & 1 & 0 & 1 & 0 & 0 & 1 & 1 & 1 & 1 & 1 & 1 & 1 & 0 & 10 \\
\hline 11 & Increasing research and marine information systems. & 11 & 0 & 0 & 1 & 1 & 0 & 1 & 1 & 1 & 0 & 1 & 1 & 1 & 1 & 1 & 1 & 1 & 1 & 13 \\
\hline 12 & Strengthening and government policies in managing mariti & 12 & 1 & 1 & 1 & 1 & 0 & 1 & 1 & 1 & 1 & 0 & 1 & 1 & 1 & 1 & 1 & 0 & 1 & 14 \\
\hline 13 & Carry out the implementation of regional empowerment & 13 & 0 & 1 & 1 & 1 & 0 & 1 & 1 & 1 & 1 & 1 & 1 & 1 & 1 & 1 & 1 & 1 & 1 & 15 \\
\hline 14 & Build maritime domain awareness & 14 & 1 & 1 & 1 & 1 & 1 & 1 & 1 & 1 & 1 & 1 & 1 & 1 & 1 & 1 & 1 & 1 & 1 & 17 \\
\hline 15 & Establish a task force to eradicate illegal fishing and terroris & 15 & 1 & 1 & 1 & 1 & 1 & 0 & 1 & 1 & 1 & 1 & 1 & 1 & 1 & 1 & 1 & 1 & 1 & 16 \\
\hline 18 & Development of human resource competency standards in n & 16 & 1 & 1 & 1 & 1 & 1 & 1 & 1 & 1 & 1 & 1 & 1 & 1 & 1 & 1 & 0 & 1 & 1 & 16 \\
\hline 17 & Development of tourism potentia & 17 & 0 & 0 & 1 & 1 & 0 & 1 & 0 & 0 & 1 & 1 & 1 & 1 & 1 & 1 & 0 & 1 & 1 & 11 \\
\hline & Y & Dep & 8 & 11 & 15 & 12 & 7 & 11 & 13 & 12 & 11 & 14 & 16 & 17 & 17 & 17 & 14 & 14 & 13 & \\
\hline
\end{tabular}


Table 6:-Reachability Matrix Final Results (after transitive testing)

\begin{tabular}{|c|c|c|c|c|c|c|c|c|c|c|c|c|c|c|c|c|c|c|}
\hline $\mathrm{X}$ & $\mathbf{1}$ & $\mathbf{2}$ & $\mathbf{3}$ & $\mathbf{4}$ & $\mathbf{5}$ & $\mathbf{6}$ & $\mathbf{7}$ & $\mathbf{8}$ & $\mathbf{9}$ & $\mathbf{1 0}$ & $\mathbf{1 1}$ & $\mathbf{1 2}$ & $\mathbf{1 3}$ & $\mathbf{1 4}$ & $\mathbf{1 5}$ & $\mathbf{1 6}$ & $\mathbf{1 7}$ & $\mathbf{D P}$ \\
\hline 1 & 1 & 0 & 0 & 0 & 1 & 1 & 1 & 0 & 1 & 0 & 1 & 1 & 1 & 1 & 1 & 1 & 1 & 12 \\
\hline 2 & 0 & 1 & 1 & 1 & 0 & 1 & 1 & 1 & 1 & 1 & 0 & 1 & 1 & 1 & 1 & 1 & 1 & 14 \\
\hline 3 & 0 & 0 & 1 & 1 & 1 & 1 & 1 & 1 & 1 & 1 & 1 & 1 & 1 & 1 & 1 & 0 & 1 & 14 \\
\hline 4 & 0 & 1 & 1 & 1 & 0 & 1 & 0 & 1 & 0 & 1 & 1 & 1 & 1 & 1 & 1 & 1 & 1 & 13 \\
\hline 5 & 1 & 0 & 1 & 0 & 1 & 0 & 1 & 0 & 0 & 1 & 1 & 1 & 1 & 1 & 1 & 0 & 0 & 10 \\
\hline 6 & 1 & 0 & 1 & 1 & 0 & 1 & 1 & 1 & 0 & 0 & 1 & 1 & 1 & 1 & 0 & 1 & 1 & 12 \\
\hline 7 & 0 & 1 & 1 & 0 & 0 & 0 & 1 & 1 & 0 & 1 & 1 & 1 & 1 & 1 & 1 & 1 & 0 & 11 \\
\hline 8 & 0 & 1 & 1 & 1 & 0 & 0 & 0 & 1 & 1 & 1 & 1 & 1 & 1 & 1 & 1 & 1 & 0 & 12 \\
\hline 9 & 1 & 1 & 1 & 0 & 0 & 0 & 0 & 0 & 1 & 1 & 1 & 1 & 1 & 1 & 1 & 1 & 1 & 12 \\
\hline 10 & 0 & 1 & 0 & 0 & 1 & 0 & 1 & 0 & 0 & 1 & 1 & 1 & 1 & 1 & 1 & 1 & 0 & 10 \\
\hline 11 & 0 & 0 & 1 & 1 & 0 & 1 & 1 & 1 & 0 & 1 & 1 & 1 & 1 & 1 & 1 & 1 & 1 & 13 \\
\hline 12 & 1 & 1 & 1 & 1 & 0 & 1 & 1 & 1 & 1 & 0 & 1 & 1 & 1 & 1 & 1 & 0 & 1 & 14 \\
\hline 13 & 0 & 1 & 1 & 1 & 0 & 1 & 1 & 1 & 1 & 1 & 1 & 1 & 1 & 1 & 1 & 1 & 1 & 15 \\
\hline 14 & 1 & 1 & 1 & 1 & 1 & 1 & 1 & 1 & 1 & 1 & 1 & 1 & 1 & 1 & 1 & 1 & 1 & 17 \\
\hline 15 & 1 & 1 & 1 & 1 & 1 & 0 & 1 & 1 & 1 & 1 & 1 & 1 & 1 & 1 & 1 & 1 & 1 & 16 \\
\hline 16 & 1 & 1 & 1 & 1 & 1 & 1 & 1 & 1 & 1 & 1 & 1 & 1 & 1 & 1 & 0 & 1 & 1 & 16 \\
\hline 17 & 0 & 0 & 1 & 1 & 0 & 1 & 0 & 0 & 1 & 1 & 1 & 1 & 1 & 1 & 0 & 1 & 1 & 11 \\
\hline Dep & 8 & 11 & 15 & 12 & 7 & 11 & 13 & 12 & 11 & 14 & 16 & 17 & 17 & 17 & 14 & 14 & 13 & \\
\hline
\end{tabular}

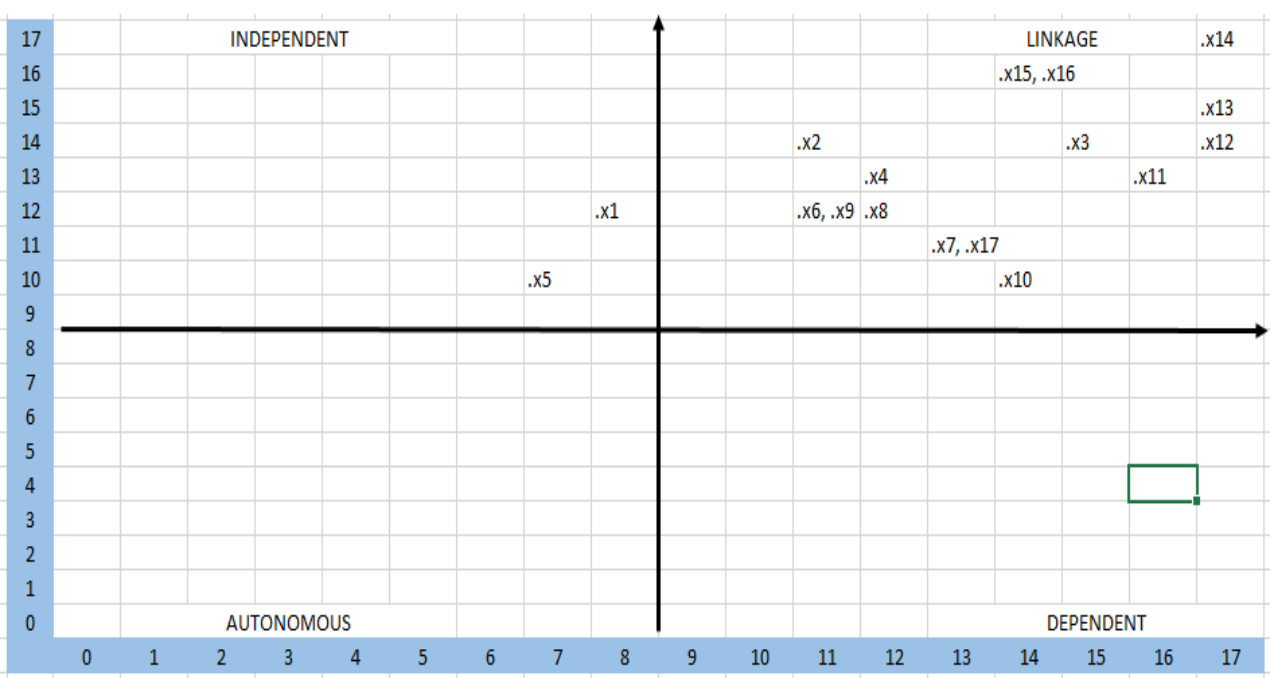

Figure 2:-Sub element classification diagram

Outgoing ISM-VAXO model for classification of supporting sub-elements based on driver power level (DP) and dependency level (D) (in figure 2), shows that there are no development support sub-elements not related to the system (sector 1 Autonomous $=0$ ). Sub-elements x2, x3, x4, x6, x7, x8, x9, x10, x11, x12, x13, x14, x15, x16 and x17 are in sector 3 (Linkage) so that they must be studied carefully because of the unstable nature of the relationship but it is very related to each other while sub-elements $\mathrm{x} 1$ and $\mathrm{x} 5$ are in sector 1 (independent) which means that it must be seen also whether the sub-elements affect or not affect sub-elements in sector 3 .

Output of the ISM-VAXO model shows the relationship hierarchical structure between the supporting sub-elements consisting of 8 levels (Figure 2) assuming the relationship that one supporting sub-element influences the benefits of the other supporting sub-elements. The model hierarchy means that sub-elements at a level are supported by the fulfillment of sub-elements at the level below. Model output shows the position of sub-elements Building maritime domain awareness (x14) as a key sub-element supporting the Maritime Potential Development Strategy system as 
the Navy's main task in supporting Food resilience which occupies the highest level (level 8) with the largest total DP.

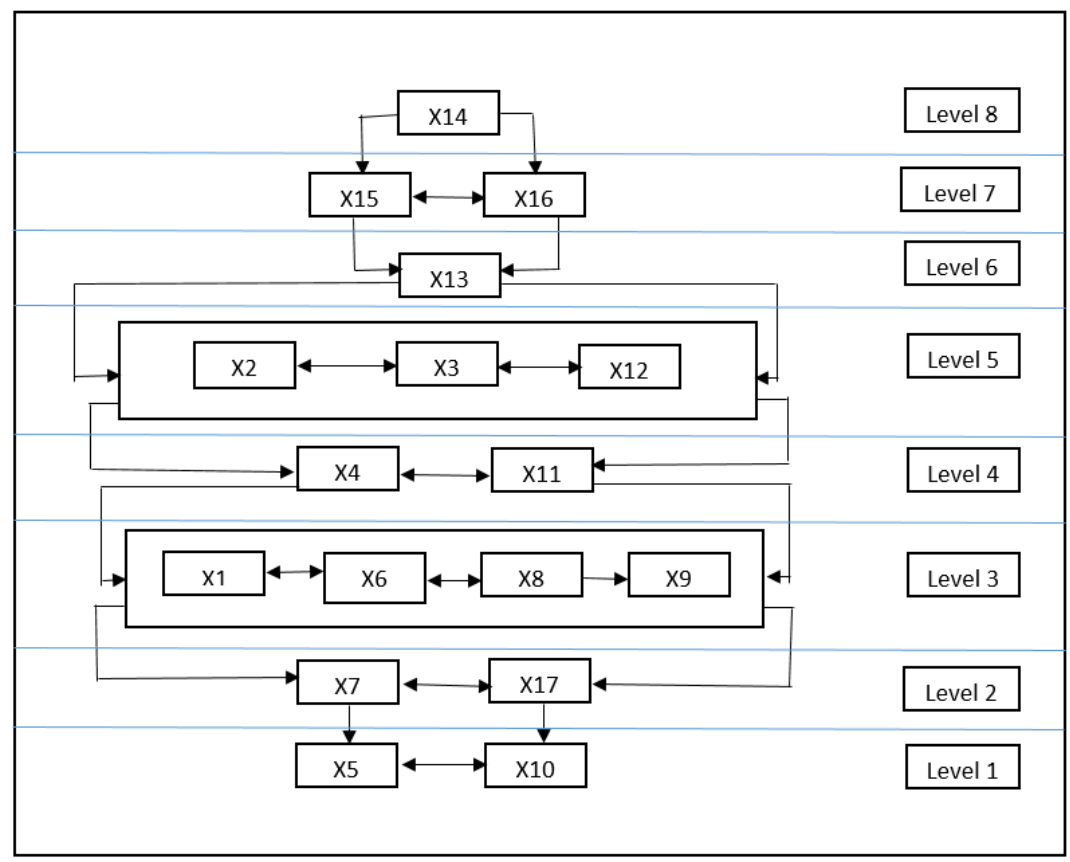

Figure 3:-The hierarchical structure of the supporting elements

1. Strategy for defense diplomacy

2. Strengthening the empowerment of maritime communities.

3. Government policy in infrastructure development in the blue spring area

4. Increasing the role of the maritime potential service to coastal communities

5. Increase marine defense systems

6. Cooperation and the development of marine technology with developed countries.

7. Adding education and marine academies, especially in coastal areas

8. Improving the welfare of fishermen

9. Establish a maritime potential management body

10. Increasing and strengthening the role of science

11. Enhancing marine research and information systems

12. Strengthening and government policies in managing maritime potential

13. Carry out the implementation of regional empowerment

14. Build maritime domain awareness

15. Establish a task force to eradicate illegal fishing and terrorism

16. Development of human resource competency standards in maritime affairs

17. Development of tourism potential

After discovering 17 strategies mapped in the SWOT Technique and added with the determination of the Level on the ISM, the next step is to analyze the strategy using the Balance Score Card.

\section{Strategy with Balance Scorecard:-}

The first step in the balanced scorecard method is to determine the vision, mission and strategy to be taken. Following are the existing visions, missions and strategies:

Vision: "To be superior in developing Maritime Potential as the main task of the Indonesian Navy to support Food Security"

Mission:

1. Doing business in building enthusiasm and love for the development of maritime potential to meet the needs of fish fulfillment and always provide the best service to the community.

2. Increasing the ability of productive and innovative Human Resources and full of creativity to support the best service to the community. 
3. Improve the ability to conduct defense diplomacy to ensure the calm and comfort of the community in their activities.

After determining the vision, mission and strategy, the next step is to determine the respective perspectives in the Balance Scorecard, and then look at the relationship between vision, mission and strategies that are used as a tool to achieve future goals. Conclusions can be drawn in the strategic objectives seen in Table 3.5

Table 7:-Recapitulation of Vision, Mission and strategies to form strategic goals

\begin{tabular}{|c|c|}
\hline Strategic & Target Perspective \\
\hline Financial & $\begin{array}{l}\text { 1. Legal umbrella for infrastructure development in the Blue } \\
\text { Spring area. } \\
\text { 2. Addition of Academy of Education in the field of marine life in } \\
\text { the Coastal area. } \\
\text { 3. The establishment of a Maritime Potential Management } \\
\text { Agency with clear legal Umbrella. } \\
\text { 4. Definite legal umbrella in the Management of Maritime } \\
\text { Potential. } \\
\text { 5. Increasing the tourism potential of the coastal region. }\end{array}$ \\
\hline Customer & $\begin{array}{l}\text { 1. A productive, innovative and creative maritime society. } \\
\text { 2. Life of fishermen is increasingly prosperous. }\end{array}$ \\
\hline Internal Process & $\begin{array}{l}\text { 1. the existence of a favorable defense diplomacy. } \\
\text { 2. Increasing the role of the Maritime Potential Service to } \\
\text { educate the public in the Sendang Biru area. } \\
\text { 3. Increasing the quality and quantity of marine defense defense } \\
\text { equipment to protect the integrity of the NKRI. } \\
\text { 4. Implementation of efforts to empower coastal communities. } \\
\text { 5. Build Mritime Domain Awareness efforts. } \\
\text { 6. The establishment of a task force to eradicate illegas fishing } \\
\text { and terrorism }\end{array}$ \\
\hline growth and learning & $\begin{array}{l}\text { 1. Collaboration with developed countries in the field of marine } \\
\text { technology. } \\
\text { 2. Application of the use of science in the field. } \\
\text { 3. Research applications and information systems in the marine } \\
\text { sector are easily accessible in the community. } \\
\text { 4. Increased Competency Standards for Human Resources in } \\
\text { the field of maritime affairs }\end{array}$ \\
\hline
\end{tabular}

After mapping all strategic targets into each perspective, then a causal link between various strategic objectives will be made. The measurement system used in making a causal relationship must refer to various objectives from the four Balance Scorecard perspectives. This image will also show changes from a strategic goal to a certain perspective and will have an impact on changes to other strategic objectives.

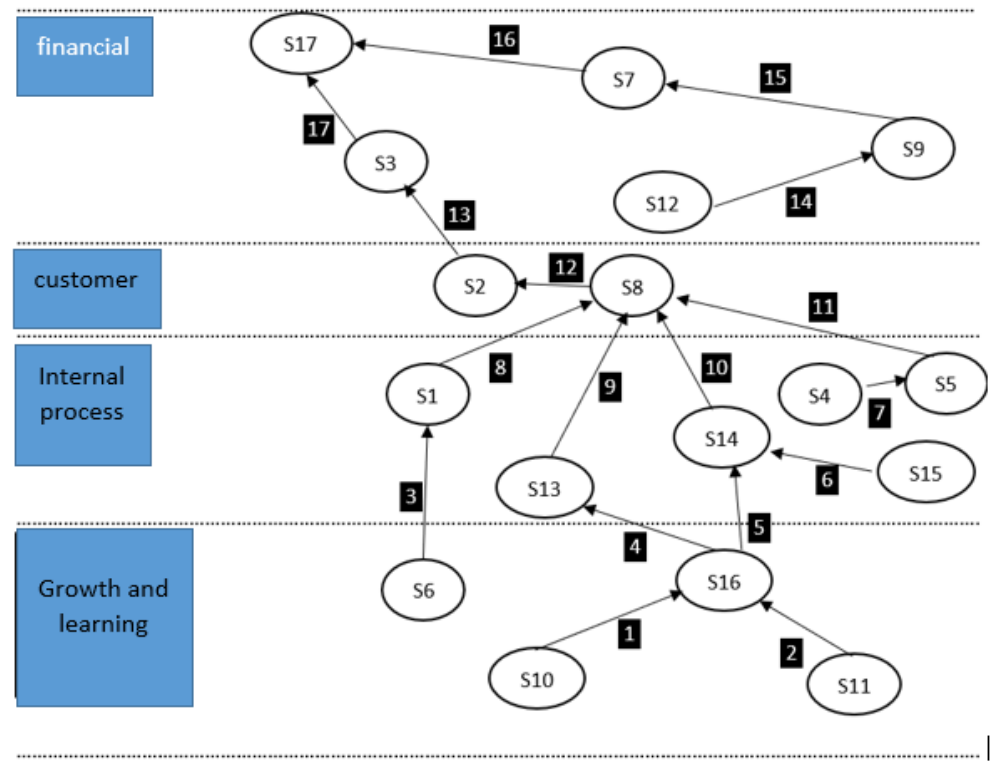

Figure 4:-Causal relationship between strategic goals

1. the existence of a favorable defense diplomacy.

2. A productive, innovative and creative maritime community.

3. Legal umbrella for infrastructure development in the Blue Spring area. 
4. Increasing the role of the Maritime Potential Service to educate the Community in the SendangBiru area.

5. Increasing the quality and quantity of sea defense defense equipment to protect the integrity of the NKRI.

6. Collaboration with developed countries in the field of marine technology.

7. Addition of Academy of Education in the field of marine life in the Coastal area.

8. Life of fishermen is increasingly prosperous.

9. The establishment of the Maritime Potential Management Agency with clear Umbrella Law.

10. Application of the use of science in the field.

11. Research applications and information systems in the marine sector are easily accessible in the community.

12. Definite umbrella umbrellas in Maritime Potential Management.

13. Implementation of efforts to empower coastal communities.

14. Build efforts on Maritime Domain Awareness.

15. The establishment of a task force to eradicate illegas fishing and terrorism.

16. Increasing the Standards of Competence of Human Resources in the field of maritime affairs.

17. Increasing the tourism potential of the coastal region.

The description of picture 4 is as follows:

1. If there is an effort to use real science in the field (applicable), it will improve the competency standards of Human Resources in the field of maritime affairs.

2. If the application of research and information systems in the field of maritime that are significantly accessible in the community, it will improve the competency standards of Human Resources.

3. If materialized Collaboration with developed countries in the field of marine technology, then increasing defense diplomacy efforts are very profitable.

4. If there is an Increase in the Standards of Competence of Human Resources in the field of maritime affairs, then efforts to empower the coastal communities will be more quickly realized.

5. If there is an Increase in the Competency Standards for Human Resources in the marine sector, then increase the efforts of Maritime Domain Awareness.

6. If a task force for eradicating illegas fishing and terrorism is formed, it will increase Maritime Domain Awareness.

7. If the efforts of the Maritime Potential Service to educate the people in the SendangBiru area are increasing, it will improve the quality and quantity of marine defense defense equipment to protect the integrity of the NKRI.

8. If the profitable defense diplomacy efforts increase, the lives of fishermen will be more prosperous.

9. If efforts are made to empower coastal communities, then the lives of fishermen will be more prosperous.

10. If Maritime Domain Awareness efforts increase, then the lives of fishermen will be more prosperous.

11. If the quality and quantity of marine defense defense equipment to protect the integrity of the NKRI increases, then the lives of fishermen will be more prosperous.

12. If the lives of fishermen are increasingly prosperous, then a productive, innovative and creative maritime community is formed.

13. If the formation of a productive, innovative and creative maritime community is getting better, then the Government's efforts to provide legal umbrella for infrastructure development in the Blue Spring region are increasingly high.

14. If there is a definite legal umbrella in the Management of Maritime Potential, then a Maritime Potential Management Agency will be established with clear legal Umbrella.

15. If a Maritime Potential Management Agency is formed with clear legal Umbrella, it will increase the Addition of Academic Education in the marine sector in the Coastal area.

16. If the addition of the Academy of Education in the field of maritime area in the Coastal area is increasing, it will increase the potential of tourism in the coastal area which will lead to an increase in the income of the community and the region.

17. If the legal umbrella for infrastructure development in the Blue Spring area increases, there will automatically be adequate infrastructure development so that it can increase the potential of tourism in the coastal areas which leads to increased income of the community and the region.

\section{Conclusions:-}

The strategy for developing maritime potential to deal with marine security threats in Malang Regency is the existence of favorable defense diplomacy, productive, innovative and creative maritime communities, legal umbrella for infrastructure development in the Blue Spring region, increasing the role of Maritime Potential Offices to educate people in the Sendang area Blue, Increasing the quality and quantity of marine defense defense equipment 
to protect the integrity of the NKRI, Collaboration with developed countries in the field of marine technology, Addition of Academy of Education in the maritime field in the Coastal area, Fishermen's life more prosperous, Establishment of Maritime Potential Management Agency with legal Umbrella clear, the application of real use of science in the field, research applications and information systems in the field of marine that are easily accessible in the community, definite legal umbrella in the management of maritime potential, implementation of community empowerment efforts Rakat coastal area, Maritime Domain Awareness efforts are established, Establishment of the illegas fishing and terrorism eradication task force, Increased Competency Standards for Human Resources in the marine sector, Increased tourism potential for coastal areas.

The evaluation model of the strategy for developing maritime potential in Malang Regency by using the SWOT Method to identify internal and external factors is then continued by using the ISM method to determine the relationship between the variables then using the Balance Score Card method to determine the target strategies to be achieved that need to get priority scale and get attention is at X14 which is Building maritime domain awareness means knowledge of what is going on in the sea in a waters region that can have an impact on security and the economy.

\section{Bibliography:-}

1. Aalam, M., Arshad, M. O., \& Khan, S. (2017). Modelling of Enablers of Innovation for SMEs: An ISM Approach. International Research Journal of Engineering and Technology (IRJET), 1798-1800.

2. Abubakar, N., \&GarbaBala Bello, P. (2013). Strengths, Weaknesses, Opportunities And Threats (SWOT) Analysis on Globacom Ltd. International Journal of Information Technology and Business Management , 8391.

3. Alao,\& Esther. (2013). Strategic Decision Making, Balanced Scorecard Profitability: Issues and Challanges. International Journal of Accounting Research .

4. Alrafadi, K. M., \&Md-Yusuf, M. (2011). Comparison between Financial Ratios Analysis and Balanced Scorecard. American Journal of Economics and Business Administration, 618-622.

5. Approach Using Interpretive Structural Model (ISM) to Determine Key Sub-Factors at Factors: Benefits, Risk Reductions, Opportunities and Obstacles in Awareness it Governance . (2018). Journal of Theoretical and Applied Information Technology, 5537-5549.

6. Attri, R., Dev, N., \& Sharma, V. (2013). Interpretive Structural Modelling (ISM) approach: An Overview. Research Journal of Management Sciences , 3-8.

7. Chaharsooghi, S. K., Beigzadeh, N., \&Sajedinejad, A. (2016). Analyzing key performance indicators of ecommerce using balanced scorecard . Management Science Letters, 127-140.

8. Chang, J.-D., \& Yang, M. (2013). Empirical Study of Fitness Industry Cases-Based on SWOT. Advances in Physical Education, 80-83.

9. Ernita,\&Firmansyah. (2015). Performance Measurement Using Balanced Scrorecard on Co-Operatives: Implication in Indonesia. International Journal Of Scientific \& Technology Research, 121-124.

10. Ge, F. (2016). SWOT Analysis of Central Economical Zone Developing E-Commerce-Take Henan for Example. Theoretical Economics Letters, 1-5.

11. George, J. P., \&Pramod, V. (2013). ISM for analysing the safety of SRRMs. International Journal of Scientific and Research Publications, 1-9.

12. Hosseini-Nasab, H., Hosseini-Nasab, A., \&Milani, A. S. (2011). Coping with Imprecision in Strategic Planning: A Case Study Using Fuzzy SWOT Analysis .iBusiness, 23-29.

13. Jain, V., \& Raj, T. (2014). Modelling and analysis of FMS productivity variables by ISM, SEM and GTMA approach. Frontiers of Mechanical Engineering, 218-232.

14. 14] Khan, U. A., Alam, M. N., \&Alam, S. (2015). A Critical Analysis of Internal and External Environment of Apple Inc. International Journal of Economics, Commerce and Management, 955-967.

15. Muda, I., Roosmawati, F., Siregar, H. S., Ramli, Manurung, H., \&Banuas, T. (2017). Performance Measurement Analysis of Palm Cooperative Cooperation Using Balanced Scorecard. The 2nd Annual Applied Science and Engineering Conference (AASEC 2017), 1-6.

16. Ofosu-Boateng, N. R. (2017). A SWOT Analysis of Maritime Transportation and Security in the Gulf of Guinea. Open Journal of Social Sciences, 1-21.

17. Osita, I. C., R., I. O., \&Justina, N. (2014). Organization's stability and productivity: the role of SWOT analysis an acronym for strength, weakness,. International Journal of Innovative and Applied Research , 23-32.

18. Panahifar, F., Byrne, P., \&Heavey, C. (2014). ISM analysis of CPFR implementation barriers. International Journal Of Production Research, 5255-5277. 
19. Ronchetti, J. L. (2006). An Integrated Balanced Scorecard Strategic Planning Model for Nonprofit Organizations . Journal of Practical Consulting, 25-35.

20. Valentin, E. K. (2005). Away With SWOT Analysis: Use Defensive/Offensive Evaluation Instead. The Journal of Applied Business Research -, 91-105. 